\title{
The Impact of Preliminary Elements for Management Innovation Adoption on the Firm's Profitability ${ }^{1}$
}

\author{
Shin-Won Seo ${ }^{1}$, Chang-Hwa Baek ${ }^{2}$ and Sung-Uk Lim ${ }^{3}$ \\ ${ }^{1}$ Researcher, Korea Institute of Science and Technology Information, \\ 245 Daehak-no, Yuseong-gu, Daejeon, 305-806, Korea. \\ ${ }^{2,3}$ Assistant Professor, Daejin University, \\ 2, 31007 Hoguk-ro, Pocheon-si, Gyoonggi-do, 487-711, Korea \\ shinwonseo@kisti.re.kr,chbaek@daejin.ac.kr \\ sulim@daejin.ac.kr, Corresponding Author
}

\begin{abstract}
Many CEOs have often introduced various types of management innovation for the firm's profitability improvement. If the firm is, however, in asituation th wich the firm is not ready to adopt those management innovations, it is not possible to achieve the goal of profit enhancement. In this study, we analyze the relationship between the preliminary elements of management innovation and profitability, and wanto introduce the key success factors of management innovation. After investigating preliminary elements of the management innovation adoption through existing literaure review, we conducted a questionnaire survey to Korean K-company. Then, by utilizing the structural equation modeling with AMOS, we analyzed the Impoct of prelinary elements of the management innovation adoption on the profitability. We found out that there are main preliminary elements of the management innovation adoption directed to profitability enhancement. From this finding, it would be possible to assist promoting successful management innovation of the company. By searching and enhancing the preliminary elements of management innovation affecting the profitability, it would be possible to reduce the innovation failure in the future business.
\end{abstract}

Keywords: Management innovation, Profitability, Subject measures, Structural equation modeling

\section{Introduction}

Many of today's businesses face diverse challenges to make profits and to survive in changing environments. Methods for businesses to maintain their competitiveness are considered determined by their organizations' innovational capability. Many theories and scholars arguments regarding management innovation or innovation consider all actions or organizations that aim to achieve efficient operations and outcomes as management innovation. Therefore, management innovation can be defined as organizational changes intentionally implemented to enhance organizational outcomes in response to environmental changes.

To strengthen domestic and international competitiveness, businesses have been introducing many management and production innovation techniques. Although businesses have used innumerable management innovation techniques, such as Reengineering, Blue Ocean, Six Sigma, and Lean Six Sigma, such management innovation techniques cannot continuously create substantive financial outcomes but pass like fashions. The reasons why management innovation cannot succeed include

${ }^{1}$ This work was supported by the Daejin University Research Grants in 2016 
organization members' resistance to businesses' implementations of innovation and the fact that managers make efforts to strengthen simple capabilities that are necessary to draw short-term outcomes rather than strengthening management innovation or organizational innovation that creates long-term outcomes[17].

Abrahamson [10] stated that the reasons for introducing management innovation are to maximize profits, increase market shares, and secure competitive advantages. Many businesses of today utilize management innovation as a measure to overcome management crises. Therefore, businesses are utilizing management innovation as the last measure for survival, not only as a measure to lead change. Accordingly, many researchers have conducted studies on success factors for management innovation. However, no study has been conducted on factors that directly affect businesses' profits. The present study drew core success factors for management innovation through the contemplation of existing management innovation success factors and investigated and analyzed the effects of success factors on businesses' profits in the cases of businesses that have been implementing innovation for three years thus far to analyze ermpirically what efforts should be made to improve businesses' profits.

\section{Background}

\subsection{Management Innovation}

The term innovation was first used by Shumpeter in reference to changes made by new products, technologies, markets, raw materials Organizations etc. Thereafter, Van de Ven [27] defined innovation as a term in reference to new ideas. Robbins[25] defined innovation as processes to select creative ideas and make useful products or services. Kim Jong-Gwan[17] stated that innovation meant systems in which new frames were constructed or systems were changed, as well as that innovation should be divided according to the forms of operation. He divided innovation into structure innovation and human resource innovation aceording to the forms of operation. Structure innovation means changes in structures, such as businesses' business structures, product structures, and organizational structures, and 1 -refers to maximizing the effectiveness of organizations by reorganizing or changing existing inefficient structures. Human resource innovation means changes in thoughts and businesses' cultural innovations. Human resource innowation involves introducing new ideas and putting them into practice so that changes can be pursued 'regarding organization members' attitudes, values, work abilities, etc. and it involves human esource-oriented innovations in organizations.

\subsection{Management Innovation Success Factor}

As management innovation is an element that plays an important role in businesses' survival and development, many studies on management innovation have been conducted. The tern innovation was first used by Shumpeter as a term that means changes made by new roducts, technologies, markets, raw materials, organizations, etc. Thereafter, Van de Ven [27] defined innovation as a term in reference to new ideas, which are approaches that newly recombined existing ideas and that are recognized as new.

Harry suggested chief executive officers' (CEOs) leadership, education, innovative organization operation systems, evaluation, and compensation as success factors for management innovation. In a study of success factors centering on domestic manufacturing businesses, Shin Dong-Seol [10] suggested management leadership, the level of innovation activity promoters, and support systems as success factors. IBM Consulting emphasized devotional leadership, outcome measurement methods, compensation systems, strategy integration, process framework, and appropriate manpower operation as success factors. Hong, SungHun[11] suggested understanding management innovation programs, CEOs' leadership, data-based management, systematic 
education and training, and operation systems as success factors. In a study of success factors centering on service businesses, Lee SunHee [22] selected leadership, the utilization of management innovation methodologies (DMAIC), education, and support systems as success factors. Chang, DaeSung [7] suggested the management's ability to support, communication, and the abilities of innovation activity promoters. Kim YeongDae [19] suggested leadership, compensation and certification systems, implementers' abilities and levels, education and training, and work standardization as success factors. Kim Tae-Hee and Oh Ji-Eun [23] suggested leadership by example, the inputs of the most talented persons, and support infrastructure construction as success factors. Park Ju-Seok and Kim Dong-Su[24] suggested strong leadership, implementers' levels, support systems, the selection of proper projects, steady maintenance, and the construction of dedicated organizations as success factors. Lee JiYoung [21] suggested prior preparation for introduction, top management's leadership, data-based analysis, education, and support system as success factors. Kim, Suyeon and Lee SangBok [18] suggested top management's support and participation, the abilities and level of innovation activity promoters, the selection of proper projects, the steady education of employees, the utilization of appropriate analysis tools, and customer-oriented management as success factors. To identify success factors for innovation, Kim Jong-Gwan[17] divided basic management innovation into two types: organizational structure innovation and human resource innovation.

\section{Research Framework}

\subsection{Concept}

In the present study, to verify the effects of success factors for innovation divided into structure innovation and human resource innovation separately, success factors were organized as shown in Table 1.

\section{Table 1. Definition of Factor}

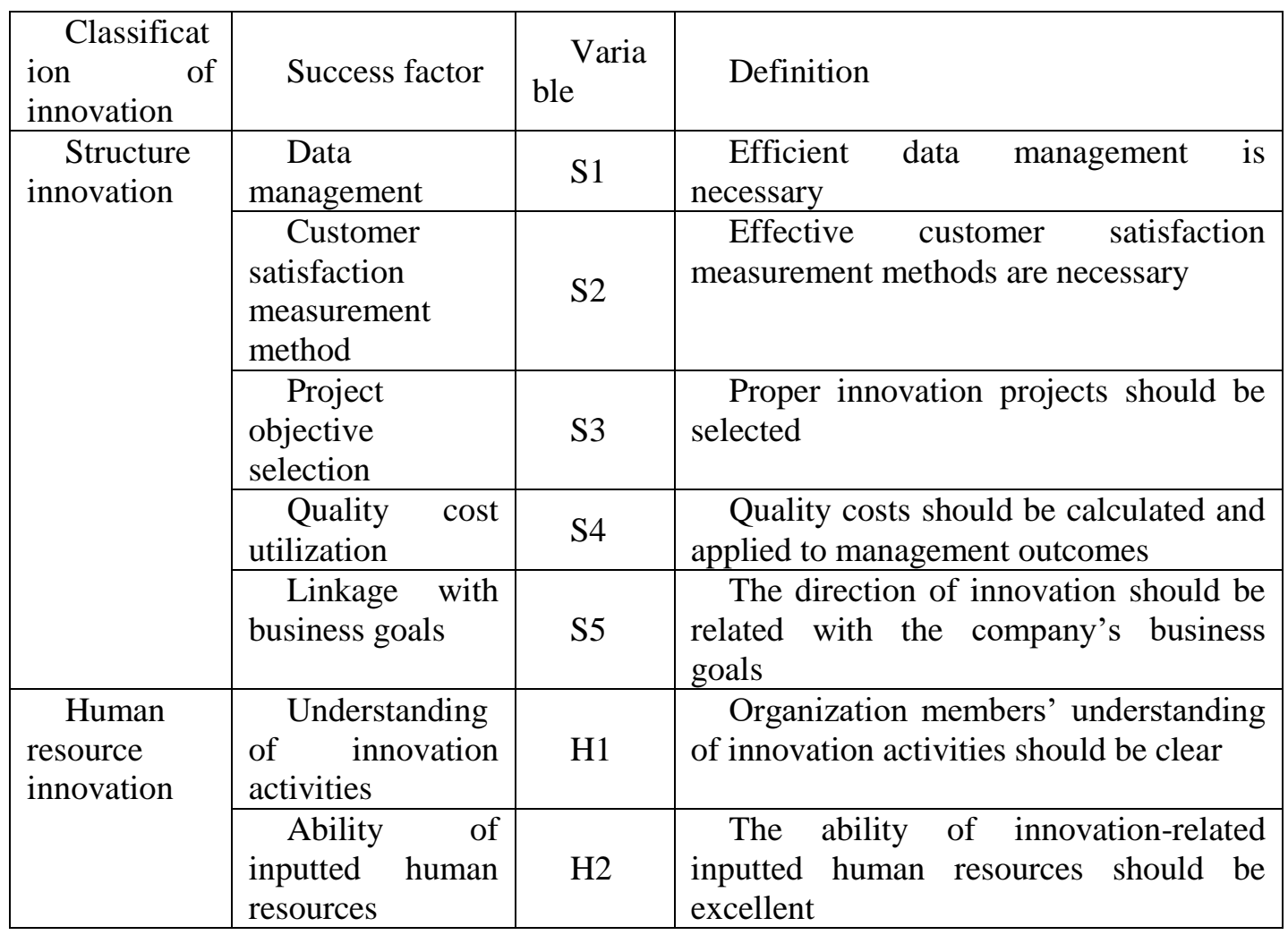




\begin{tabular}{|l|l|c|l|}
\hline & $\begin{array}{c}\text { Understanding } \\
\text { of innovation } \\
\text { methods }\end{array}$ & $\mathrm{H} 3$ & $\begin{array}{c}\text { The understanding of innovation } \\
\text { methodologies should be clear }\end{array}$ \\
\cline { 2 - 4 } $\begin{array}{c}\text { Reinforcement } \\
\text { of innovation } \\
\text { education }\end{array}$ & $\mathrm{H} 4$ & $\begin{array}{l}\text { Education for innovation should be } \\
\text { reinforced }\end{array}$ \\
$\begin{array}{l}\text { Leaders' } \\
\text { understanding of } \\
\text { innovation }\end{array}$ & $\mathrm{H} 5$ & $\begin{array}{l}\text { Leaders' understanding of innovation } \\
\text { activities should be clear }\end{array}$ \\
\hline
\end{tabular}

Based on the Table, a study model, as shown in Figure 1, was set up.

\subsection{Process}

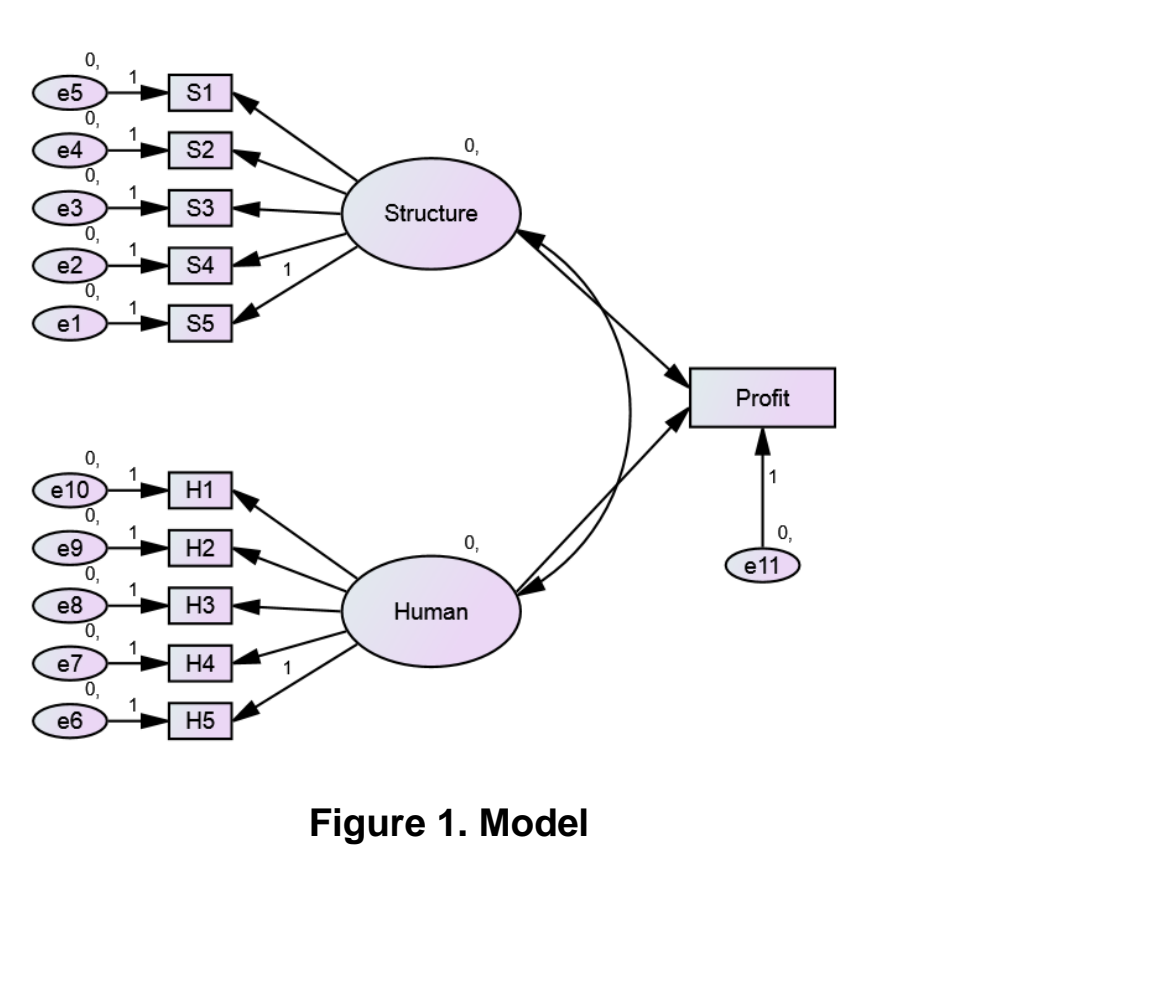

Core elements of strueture innovation are data management, a customer satisfaction measurement method, the selection of innovation projects' objectives, the utilization of quality costs, and a linkage with business goals, and study hypotheses indicating that these core elements of innovation should have positive effects on businesses' profits were set up as follows.

S 1: Structure innovation should have positive (+) effects on business profits.

$S$ (1) Data management should have positive (+) effects on business profits.

S) 1-2: Customer satisfaction measurement methods should have positive (+) effects on business profits.

S 1-3: The selection of innovation projects' objectives should have positive $(+)$ effects on business profits.

S 1-4: The utilization of quality costs should have positive (+) effects on business profits.

S 1-5: A linkage with business goals should have positive (+) effects on business profits.

The core elements of human resource innovation include the understanding of innovation activities, the abilities of inputted human resources, the understanding of innovation methods, the reinforcement of innovation education, and leaders' 
understanding of innovation, and study hypotheses indicating that these core elements of innovation, as related to humans, should have positive effects on businesses' were set up as follows.

$\mathrm{H}$ 1: Human resource innovation should have positive (+) effects on business profits.

$\mathrm{H} \mathrm{1-1:}$ The understanding of innovation activities should have positive $(+)$ effects on business profits.

H 1-2: The abilities of inputted human resources should have positive $(+)$ effects on business profits.

H 1-3: The understanding of innovation methods should have positive (+) effects on business profits.

H 1-4: The reinforcement of innovation should have positive (+) effects on business profits.

H 1-5: Leaders' understanding of innovation should have positive (+) effects on business profits.

\subsection{Sample Design}

In the present study, to obtain data for analysis, offline questionnatre surveys were conducted at six business places of K Company for 10 days from Octobe 20 to 29, 2014. Questionnaire scales were composed using five-point scales. The questionnaire surveys were conducted with 535 participants of K Company's innovation projects. Of the collected questionnaire responses, 470 responses, excluding unfatthful responses, were used in the analyses. Percentages of respondents by position are as follows: officers $4 \%$, team leaders $10 \%$, and team members $86 \%$

Reliability tests and factor analyses were conducted using SPSS 21.0 as methods of analyzing the data used in the presentstudy. Structural equating model analyses were conducted using AMOS 21.0.

Step 1: Reliability Analysis

The reliability of individual factors was tested through Cronbach's $\alpha$ coefficients. In general, a factor with a Cronbach's a coefficient value no smaller than 0.6 is judged reliable and a factor with a Cronbach s $\alpha$ coefficient value no smaller than $0.8-0.9$ is judged highly reliable [27]. The Cronbach's $\alpha$ coefficient values of all factors were shown to be 0.859 , indicating a high reliability, and all the Cronbach's $\alpha$ coefficient values of individual coefficients were at least 0.8 , indicating that the questionnaires were valid.

\section{Table 2. Cronbach's Alpha Coefficient}

\begin{tabular}{|l|l|l|}
\hline Variable & Cronbach alpha \\
\hline Data management & $\mathrm{S} 1$ & .841 \\
Customer satisfaction measurement method & $\mathrm{S} 2$ & .848 \\
Project objeetive selection & $\mathrm{S} 3$ & .844 \\
Quality cost utilization & $\mathrm{S} 4$ & .841 \\
Linkage with business goals & $\mathrm{S} 5$ & .858 \\
Onderstanding of innovation activities & $\mathrm{H} 1$ & .841 \\
Ability of inputted human resources & $\mathrm{H} 2$ & .838 \\
Understanding of innovation methods & $\mathrm{H} 3$ & .833 \\
Reinforcement of innovation education & $\mathrm{H} 4$ & .880 \\
Leaders' understanding of innovation & $\mathrm{H} 5$ & .830 \\
\hline
\end{tabular}

Step 2: Factor Analysis

To examine whether the questions included in the tests in the present study properly reflect the factor structures assumed in the theory, exploratory factor analyses were conducted using the orthogonal rotation method (Varimax rotation) and as questions with 
1 or larger eigenvalues are qualified as factors, questions with 1 or larger eigenvalues were classified and analyzed.

Table 3. Output of Varimax's Rotation

\begin{tabular}{|l|l|l|}
\hline \multirow{2}{*}{ Variable } & Factor \\
\cline { 2 - 3 } & 1 & 2 \\
\hline Data management & .755 & .277 \\
Customer satisfaction measurement method & .724 & .167 \\
Project objective selection & .721 & .251 \\
Quality cost utilization & .716 & .328 \\
Linkage with business goals & .555 & .100 \\
Understanding of innovation activities & .197 & .808 \\
Ability of inputted human resources & .296 & .760 \\
Understanding of innovation methods & .454 & 678 \\
Reinforcement of innovation education & .073 & .669 \\
Leaders' understanding of innovation & .515 & .655 \\
Eigenvalue & 3.039 & 2.852 \\
Variance & 30.386 & 28.516 \\
\hline
\end{tabular}

To test the causal relationships between the constructs of the study model, path models were used through covariance structure analyses. To judge the goodness-of-fit of the structure models, models with a CFI, IFI, and NFI not smaller than 0.9 were judged as desirable and those with an RMSEA O.J or smatler were judged as fitting. In addition, models with construct reliability (CR), values of 0.7 or higher used to measure internal consistency are judged as highly reliable. According to the results of the present study, as $\mathrm{CFI}=0.930, \mathrm{IFI}=0.931, \mathrm{NFI}=0$, and RMSEA $=0.090$, the study model can be judged as highly reliable.

Table 4. Relation of Factors

\begin{tabular}{|c|c|c|c|c|c|c|c|}
\hline Factor & & & Estimate & S.E. & C.R. & \multicolumn{2}{|c|}{ P-value } \\
\hline Linkage with business goals & $\rightarrow$ & Project & 1.000 & & & 0.000 & Accept \\
\hline Quality cost utilization & $\rightarrow$ & Project & 2.207 & .254 & 8.706 & 0.000 & Accept \\
\hline Project objective selection & $\rightarrow$ & Project & 1.826 & .215 & 8.485 & 0.000 & Accept \\
\hline $\begin{array}{l}\text { Customer satisfaction measurement } \\
\text { method }\end{array}$ & $\rightarrow$ & Project & 1.690 & .208 & 8.113 & 0.000 & Accept \\
\hline Data management & $\rightarrow$ & Project & 2.171 & .248 & 8.746 & 0.000 & Accept \\
\hline $\begin{array}{l}\text { Leaders' understanding of } \\
\text { innovation }\end{array}$ & $\rightarrow$ & Human & 1.000 & & & 0.000 & Accept \\
\hline $\begin{array}{l}\text { Reinforcement of innovation } \\
\text { education }\end{array}$ & $\rightarrow$ & Human & .929 & .091 & 10.184 & 0.000 & Accept \\
\hline $\begin{array}{l}\text { Understanding of innovation } \\
\text { activities }\end{array}$ & $\rightarrow$ & Human & .876 & .046 & 18.875 & 0.000 & Accept \\
\hline Ability of inputted human resources & $\rightarrow$ & Human & .853 & .047 & 18.289 & 0.000 & Accept \\
\hline $\begin{array}{l}\text { Understanding of innovation } \\
\text { methods }\end{array}$ & $\rightarrow$ & Human & .800 & .048 & 16.631 & 0.000 & Accept \\
\hline Profit & $\leftarrow$ & Project & .046 & .250 & .183 & 0.855 & Reject \\
\hline Profit & $\leftarrow$ & Human & .793 & .093 & 8.522 & 0.000 & Accept \\
\hline
\end{tabular}




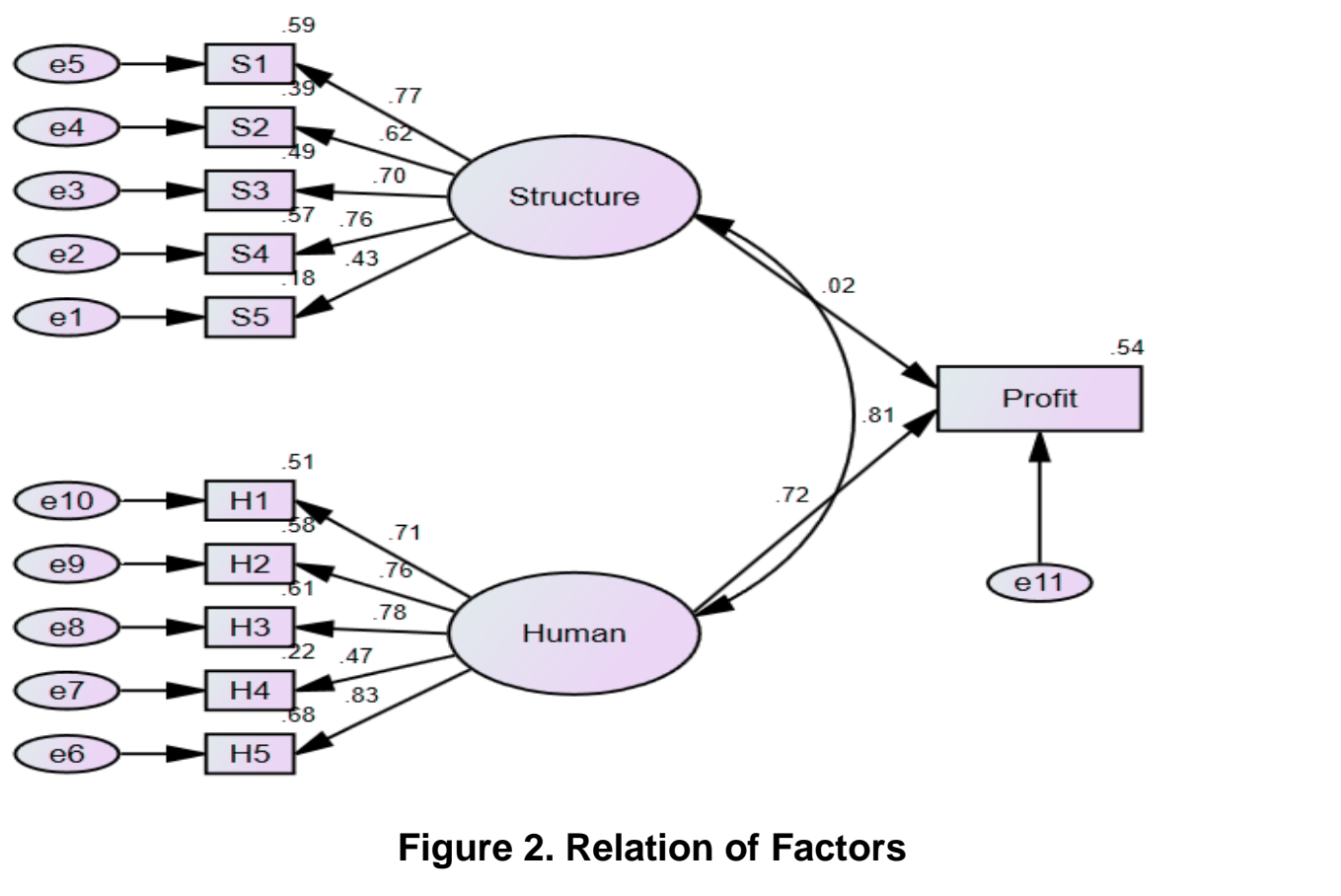

To review the results of the analyses in the present study, the hypothesis that core factors of structure innovation should hâye positive $(+)$ effects on businesses profits was dismissed and the hypothesis that human resource inovation should have positive $(+)$ effects on businesses' profits was adopted. The results indicated that although the introduction of proper methodologies was thought to be an important factor for achieving innovation in the introduction of generally Kknown innovation, the respondents were thinking that unless human resources vrere substantially changed, businesses' profits would not change.

\section{Conclusion}

Althougb the necessity and importance of management innovation are recognized, empirical studies of the success factors for management innovation have been mainly those conducted through large business cases and basic research into several small- and medium-sized businesses; no study has analyzed the thoughts of the personnel of businesses in which innovation was in progresses. In addition, analyses of success factors for management innovation mainly emphasized leadership, education, innovation activity promoters, process framework, and appropriate human resource operation. In the present study, 10 factors were selected from among factors that were frequently mentioned out of the aforementioned factors and factors that were considered the most important in the field. The selected factors were data management, customer satisfaction measurement methods, the selection of project objectives, the utilization of quality costs, a linkage with business goals, the understanding of innovation activities, the abilities of inputted human resources, the understanding of innovation methods, and the reinforcement of innovation education. Factor analyses were conducted with the 10 factors, and based on the results, the factors were divided into structure innovation factors and human resource innovation factors. The relationships between the two types of innovation factors and profits were structure analyzed, and according to the results, the structure innovation factor had weak effects, while human resource innovation factors had strong effects. Rather than the importance of innovation methodologies, this implies that personnel's consider that innovation affects businesses' profits in the field, thereby suggesting that how 
organization members' mental attitudes should be changed must be considered more importantly before implementing innovation rather than deliberating on what management innovation methodologies should be introduced. However, the present study has the following limitations. First, rather than using quantitative indices of actual profits, the present study used qualitative questionnaires to analyze whether innovation affects profits. Therefore, later, quantitative indices and management innovation should be introduced for analysis. Second, the present study conducted surveys with the personnel of one business. Therefore, surveys should be conducted using diverse businesses that are implementing management innovation.

\section{References}

[1] Y.-K. Ahn, H.-G. Kim and S.-R. Lee, "A study about the impacts of firm's innovation competence on management performance: Focusing on the SME in the medical equipment industry", Korean Journal of Business Administration, vol. 23, no. 4, (2010), pp. 2305-2328.

[2] Y.-K. Ahn, H.-G. Kim and S.-R. Lee, "A study about the impacts of firm's innovation competence on management performance: Focusing on the SME in the medical equipment industry", Korean Journal of Business Administration, vol. 23, no. 4, (2010), pp. 2305-2328.

[3] G. Akman and C. Yilmaz, "Innovative capability, innovation strategy and market orientation: An empirical analysis in Turkish software industry", International Journal of Innovation Management, vol. 12, no. 1, (2008), pp. 69-111.

[4] J. Antony and R. Banuelas, "Critical success factors for the successful implementation of Six-Sigma projects in organization", The TQM Magazine, vol. 14, o. 2, (2002), pp. $92-99$.

[5] A. Brun, "Critical success factors of Six Sigma implementation in Italian companies", Int. J. Production Economics, vol. 131, (2011), pp. 158-164.

[6] R. A. Burgelman, C. M., Christensen and S. C. Wheelwright, "Strategic Management of Technology and Innovation", 5th edi, New York: McGraw-Hill, (2009).

[7] D.S. Chang, J.G. Yang and I.C. Whang, "An Empirical Study on Performance of Six Sigma Tools in Korean Service Industry", Journal of the Korean Society for Oudity Management, vol.32, no. 1, (2004), pp. $1-20$.

[8] J. H. Cho and J.-S. Jang, "Selection S1x Sigma Key Ingredients", Journal of the Korean Society for Quality Management, vol. 34 no. 4, (2006), pp. 22-33

[9] E. Abrahamson, "Managerial Fads and Fashions. The Diffusion and Rejection of Innovations", Academy of Management vol. 16, no. 3, (1991), pp. 586-612.

[10] G.J. Hahn, W.J. Hill and R. W. Hoerl, The Impact of Six Sigma Improvement-A Glimpse into the Future of Statics", The American Statician, (2016), pp. 208-215.

[11] S.H. Hong, S.B. Kin. H.M. Kwon M.K. Lee and Sung, "Six Sigma Business Breakthrough Strategy", Journal of the Korean society for quality management, vol 27, no. 1, (1999), pp. 223-231.

[12] K.H. Hwang Jeaik, Hwang, Jung, Inkeuk and C.W. Kang, "Analysis of success factors of QM in korea", Paper presented at he, (2015), pp. 627-635.

[13] G.-S. Jang, Moon, Sung-11 and J.-S. Song, "The effects of SCM success factors on process innovation and business performance", Journal of the Korean Society of Supply Chain Management, vol. 15, no. 1, (2015), pp. 43-51.

[14] P.-O. Jesus, G.-B. Javier and G. Jesus, "Total quality management as a forerunner of business innovation câpability", Technovation, vol. 26, (2006), pp. 1170-1185.

[15] K. Kim and W. Hong, "Effect of Firm's activities on their performances", Journal of Korea Technology Innovation Society, vol. 14, no. 2, (2011), pp. 373-404.

[16] K. Kim and W. Hong, "Effect of Firm's activities on their performances", Journal of Korea Technology Innovation Society, vol. 14, no. 2, (2011), pp. 373-404.

[17] JK Kim, "A Study On The Relation Between Management Innovation Factors And Organizational Commitment", Journal of Korean Academy of Human Resource Management, vol. 15, no. 3, (2008), pp. 49-62.

[18] S. Kim and S.B. Lee, "Study on Six Sigma success factors in the service industry. Journal of Quality and Sustainability", Conference Proceedings, Korea Society for Quality Management, vol. 4, (2006).

[19] Y.D. Kim, "The Effect of Relationship Marketing on the Quality and Channel Performance in Distribution Channel Industry", Journal of Korea Industrial Economic Association, vol. 15, no. 5, (2002), pp. 253-272.

[20] G.-D. Lee and H.-G. Park, "A study on the effect of the relationships among the 6 sigma success factors, knowledge creation and performance in the corporate", Review of Business \& Economics, vol. 27, no. 5, (2014), pp. 2247-2275.

[21] J.-Y. Lee and J.-H. Jee, "Moderating Effects of Emotional Intelligence on the Relationships between Job Demand and Burn-out: Focused on Tourism Employees", Human Resource Management Research, vol. 14, no. 4, (2007), pp. 277 294. 
[22] S.H. Lee and G.W. Gu, "A Study on the Effect of the Six Sigma Program on Management Efficiency in Tourist Hotels" Journal of Travel Study, (2001), vol. 13, pp. 55-73.

[23] J. E.Oh and D.K. Kim, "An Exploratory Study on the University Educational Service Quality Evaluation -Focusing on Undergraduate Students Majoring in Tourism", Korean Journal of Hospitality \& Tourism, vol. 17 , no. 6 , (2008), pp. 221-239.

[24] J. S.Park and D. S.Kim, "The Research in the Application of Six Sigma in Manufacturing and Service Industry", Conference Book of Korean Institute of Industrial Engineers, (2004), pp. FB6-13 - 16

[25] D. I. Prajogo, "The Relationship between Innovation and Business Performance-A Comparative Study between Manufacturing and Service Firms", Knowledge and Process Management, vol. 13, no. 3, (2006), pp. 218-225.

[26] S. Robbins, "Comportamiento Organizacional", Teoría y Práctica, Prentice-Hall, México, (1996).

[27] A. H Van de Ven, "Central Problems in the Management of Innovation", Management Science, vol. 32, no. 5, (1986), pp. 590-607.

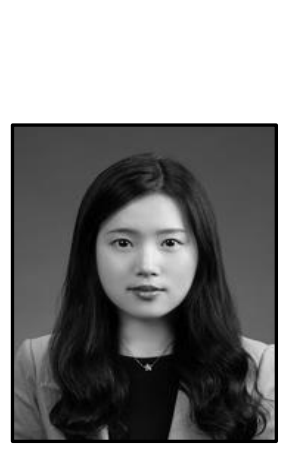

\section{Authors}

Shinwon Seo, she is curruntly working as a Researcher in Technology intelligence Division at Korea Institute of Science and Technology Information, Seoul, Korear She received the B.S. degree from Hanbat National University and an M.S degree in Industrial Engineering from Sungkyunkwan University, Korea. Her current research is concentrated on Bigdata, Policy/Research, Quality management and R\&D management

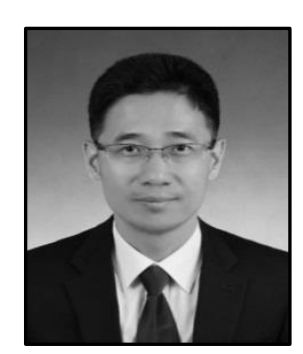

Changhwa Baek, he is an Assistant Professor of Industrial \& Management Engineering a Daejin University, Pocheon, Korea. He received the B.S, from Hansung University and an M.S. in Industrial Engineering from Korea University. He worked for Pantech, Seoul, Korea (2001-2015) and Hyundai Electronics Inc. Seoul, Koea (20002001. His reseatch interests are in Quality management, R\&D management and Prođuct planning.

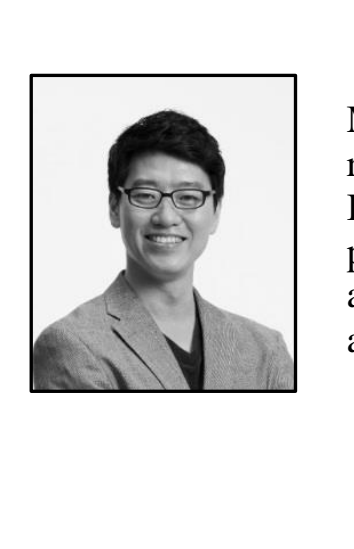

Sunguk Lim, he is an Associate Professor of Industrial \& Management Engineering at Daejin University, Pocheon, Korea. He received the B.S. from Hansung University and an M.S. and Ph.D. in Industrial Engineering from Sungkyunkwan University. He has published numerous books and academic articles. He is also working as Editor in several academic journals in Korea. His research interests are in quality management and quality measurement index. 
International Journal of Hybrid Information Technology

Vol. 9, No.10 (2016)

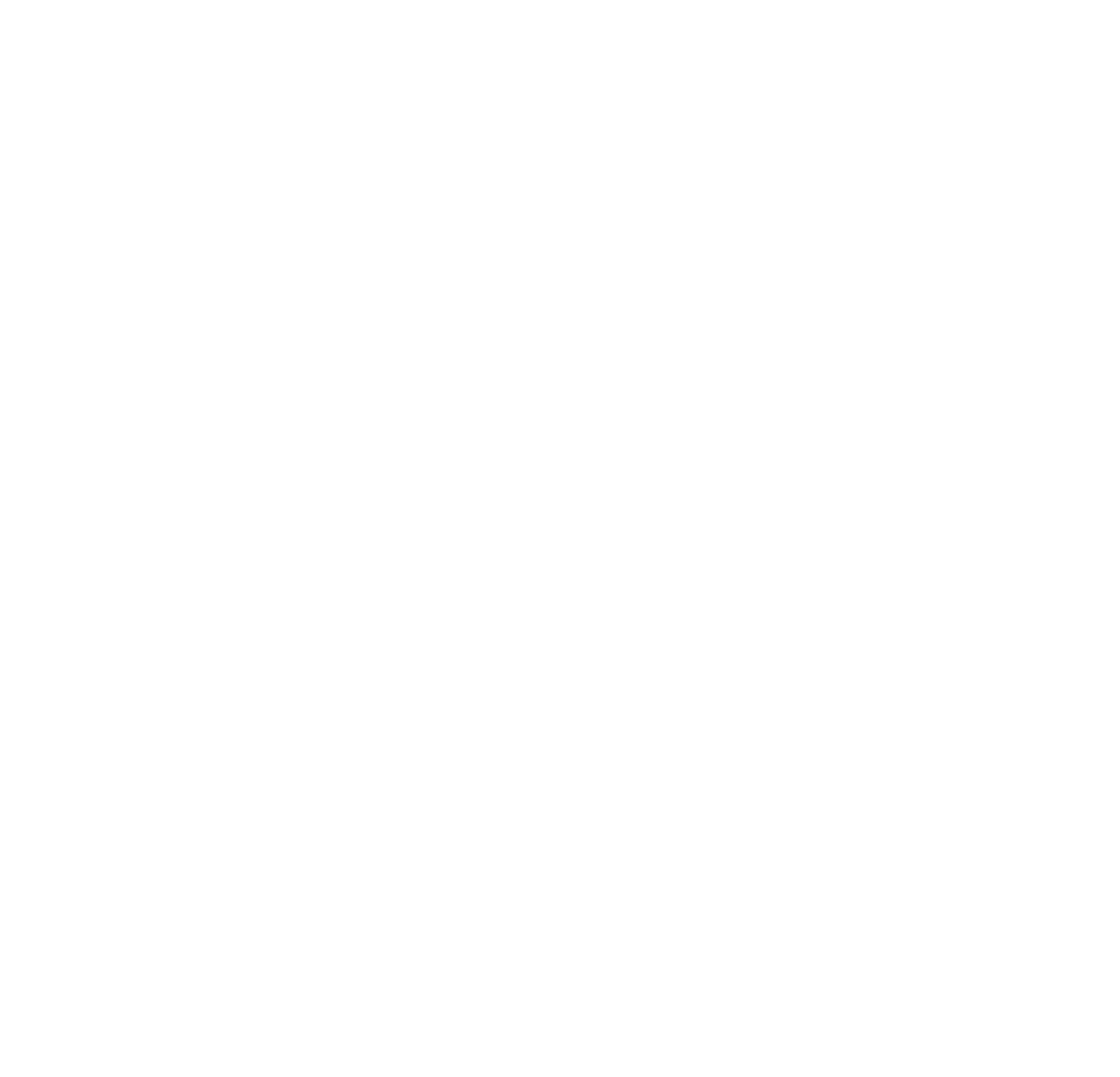

